Volume 5 Mei, 2020 (28-40)
$\frac{\text { http://ejournal.upi.edu/index.php/JTIKOR }}{\text { doi: } 10.17509 / \text { itikor.v5i1.24895 }}$

\title{
Perbedaan Jenis Kelamin, Usia, dan Body Mass Index (BMI) Hubungannya dengan Kebugaran Jasmani Lanjut Usia
}

\author{
Seni Oktriani ${ }^{{ }}$, Nurlan Kusmaedi ${ }^{2}$, Hamidie Ronald Daniel Ray ${ }^{2}$, Anang Setiawan ${ }^{1}$ \\ ${ }^{1}$ Program Studi PJKR, STKIP Nahdlatul Ulama Indramayu, Jawa Barat, Indonesia \\ ${ }^{2}$ Program Studi Ilmu Keolahragaan, FPOK, Universitas Pendidikan Indonesia, Jawa Barat, \\ Indonesia
}

\section{Info Artikel}

\section{Kata Kunci:}

Body Mass Index, Jenis Kelamin,

Kebugaran Jasmani, Lansia, Usia

Keywords:

Body Mass Index, Gender, Physical Fitness, Elderly, Age

Alamat korespondensi:
J1. Raya Kaplongan No.28,
Kaplongan, Karangampel,
Kabupaten Indramayu, Jawa
Barat 45283
E-mail:
senioktriani@stkipnu.ac.id

\begin{abstract}
Abstrak
Permasalahan kebugaran jasmani pada lanjut usia akan berhubungan dengan aktivitas yang dilakukan oleh lanjut usia tersebut termasuk dampak dari aktivitas jasmani atau olahraga yang dilakukan secara rutin (teratur dan terukur). Terdapat banyak aspek yang dapat mempengaruhi atau memiliki hubungan dengan kebugaran jasmani lanjut usia seperti jenis kelamin, usia, dan body mass index (BMI). Tujuan dari penelitian ini adalah untuk mengetahui hubungan antara jenis kelamin, usia, dan body mass index (BMI) dengan kebugaran jasmani lanjut usia. Metode penelitian yang digunakan adalah penelitian kuantitatif dengan desain korelasional. Teknik pengambilan sampel pada penelitian ini adalah purposive sampling dengan jumlah sampel adalah 37 orang lanjut usia yang memenuhi kriteria penelitian dengan usia 60 tahun ke atas. Hasil penelitian ini menunjukkan nilai probabilitas sebesar 0,012 yang artinya bahwa terdapat hubungan antara jenis kelamin, usia, dan body mass index (BMI) dengan kebugaran jasmani lanjut usia. Kesimpulannya bahwa beberapa faktor seperti jenis kelamin, rentang usia, dan body mass index (BMI) pada masing-masing lansia akan berhubungan dengan tingkat kebugaran jasmaninya. Sehingga, hal ini dapat dijadikan sebagai rujukan bagi para lansia untuk selalu menjaga kebugaran jasmani dengan memperhatikan faktor-faktor tersebut.
\end{abstract}

\begin{abstract}
The problem of physical fitness in the elderly will be related to the activities carried out by the elderly, including the impact of physical activities or sports carried out regularly (regularly and measured). There are many aspects that can affect or have a relationship with elderly physical fitness such as gender, age, and body mass index (BMI). The purpose of this study was to determine the relationship between sex, age, and body mass index (BMI) with physical fitness of the elderly. The research method used is quantitative research with a correlational design. The sampling technique in this study is purposive sampling with the number of samples is 37 elderly people who meet the research criteria with the age of 60 years and over. The results of this study indicate the probability value of 0.012 which means that there is a relationship between sex, age, and body mass index (BMI) with physical fitness of the elderly. The conclusion is that several factors such as gender, age range, and body mass index (BMI) in each elderly will be related to the level of physical fitness. So, this can be used as a reference for the elderly to always maintain physical fitness by taking into account these factors.
\end{abstract}




\section{PENDAHULUAN}

Perjalanan hidup manusia akan melalui beberapa fase kehidupan (tumbuh-kembang) mulai dari manusia itu lahir, masa anak-anak, remaja, dewasa, hingga lansia (Papalia, Olds, \& Feldman, 2007). Salah satu karakteristik unik pada fase lansia bahwa manusia akan seolah kembali ke fase anak-anak terutama secara mental. Sedangkan secara fisik, pada fase ini ditunjukkan dengan adanya degradasi kemampuan pada kualitas gerak (Oktriani, Solihin, \& Komariyah, 2019).

Organisasi Kesehatan Dunia (World Health Organization, n.d.) menggolongkan lansia menjadi empat yaitu usia pertengahan (middle age) adalah 45-59 tahun, lanjut usia (elderly) adalah 60-74 tahun, lanjut usia tua (old) adalah 75-90 tahun dan usia sangat tua (very old) diatas 90 tahun. Azizah, (2011) menjelaskan bahwa lanjut usia adalah seseorang yang mengalami pertambahan umur disertai dengan penurunan fungsi fisik yang ditandai dengan penurunan massa otot serta kekuatannya, penurunan laju denyut jantung maksimal, peningkatan lemak tubuh dan penurunan fungsi otak. Sedangkan menurut Peraturan Pemerintah Republik Indonesia Nomor 43 Tahun 2004, lanjut usia adalah seseorang yang telah mencapai usia 60 (enam puluh) tahun ke atas. Ketika seseorang memasuki usia lanjut, maka tubuhnya tidak akan mengalami perkembangan lagi. Dari beberapa penjelasan di atas, maka dapat disimpulkan bahwa lanjut usia adalah orang yang telah mengalami penurunan fungsi organ tubuh, sehingga dalam melakukan kegiatan sehari-hari harus memperhatikan beberapa hal, antara lain jenis aktivitas yang dilakukan, intensitas kegiatan, dan harus disesuaikan dengan kemampuan fisiknya. Jenis aktivitas olahraga yang cocok untuk lansia adalah olahraga kesehatan atau kebugaran (Oktriani et al., 2019). Mengenai olahraga kesehatan, Giriwijoyo, Komariyah, \& Kartinah, (2007) menyatakan bahwa olahraga kesehatan adalah olahraga untuk memelihara dan/atau meningkatkan derajat kesehatan dinamis, sehingga orang bukan saja sehat dikala diam (sehat statis) tetapi juga sehat serta mempunyai kemampuan gerak yang dapat mendukung setiap aktivitas dalam peri kehidupannya seharihari (sehat dinamis) yang bersifat rutin, maupun untuk keperluan rekreasi dan/atau mengatasi keadaan gawat darurat.

Dengan melakukan aktivitas olahraga kesehatan, lansia akan dapat mempertahankan kebugaran jasmani yang telah dimiliki sebagai sarana untuk melakukan berbagai aktivitas sehari-hari (Justine, Azizan, Hassan, Salleh, \& Manaf, 2013). Upaya yang dapat dilakukan melalui aktivitas jasmani atau olahraga kesehatan secara teratur dan terukur bertujuan untuk menjaga penurunan kualitas kemampuan gerak secara perlahan dan tidak mengalami penurunan secara drastis serta menekan depresi pada lansia (Salguero, Martínez-García, Molinero, \& Márquez, 2011). Banyak macam aktivitas jasmani atau olahraga kesehatan yang dapat dilakukan oleh lansia, seperti senam Tai Chi, senam jantung, berjalan di batu refleksi, dan jalan santai (Setiawan \& Oktriani, 2017). Kegiatan-kegiatan olahraga tersebut dapat dilakukan secara mandiri ataupun berkelompok di ruang terbuka atau di klub/sanggar kebugaran khusus lansia.

Kebugaran jasmani adalah kesanggupan tubuh untuk melakukan aktivitas tanpa mengalami kelelahan yang berarti (Kyröläinen, Santtila, Nindl, \& Vasankari, 2010). Seseorang akan mendapatkan tingkat kebugaran yang baik jika rutin melakukan aktivitas jasmani atau olahraga (Rauner, Mess, \& Woll, 2013). Aktivitas jasmani yang dilakukan oleh manusia akan berhubungan erat dengan kualitas hidup, kesehatan, dan kesejahteraan (Chen, Hui, Lang, \& Tao, 2016). Sebaliknya, apabila manusia tidak melakukan aktivitas jasmani sesuai kebutuhannya maka kemungkinan besar akan mudah terjangkit penyakit akibat kurang gerak (hipokinetik) seperti diabetes tipe 2 (Gram, Dahl, \& Dela, 2014). Tingkat aktivitas jasmani yang rendah akan meningkatkan risiko obesitas dan banyak penyakit kronis lain termasuk penyakit jantung koroner, diabetes dan kanker usus (Ogilvie, Lamb, Ferguson, \& Ellaway, 2011). Akan tetapi tidak dapat dihindari bahwa 
penurunan aktivitas jasmani secara umum akan terjadi pada masa lansia seiring dengan penurunan kemampuan otot, munculnya rasa kaku, dan sakit pada persendian (Dai Jun, 2015).

Gaya hidup aktif/active life style harus dilakukan sepanjang hayat untuk menunjang kehidupan manusia, begitu juga lansia. Hasil penelitian menunjukkan bahwa banyak manfaat dari partisipasi dalam latihan aktivitas jasmani bagi lansia (Setiawan \& Oktriani, 2017), diantaranya memperbaiki fungsi kardiovaskuler, menurunkan tekanan darah, dan meningkatkan kapasitas kerja. Latihan aktivitas fisik cukup dilakukan dua setengah jam per minggu untuk mengurangi risiko penyakit kronis secara signifikan Namun, penelitian lain menunjukkan bahwa latihan sekitar 100 menit per hari lebih baik lagi (Van Den Brink et al., 2005). Program latihan bagi lansia diantaranya jenis latihan kardiovaskuler, kekuatan otot, fleksibilitas, dan koordinasi dengan frekuensi 3 sampai 6 kali perminggu, durasi 50 sampai 60 menit persesi latihan dengan intensitas yang rendah antara 60\% - 70\% dari denyut nadi maksimal (Emerson, 1991; Van Camp \& Boyer, 1989). Selain untuk menjaga kesehatan dan kebugaran lansia, program latihan aktivitas jasmani yang disusun juga dapat digunakan sebagai alat terapi (Short \& Leonardelli, 1987). Program latihan bagi lansia yang dilakukan di luar rumah dapat meningkatkan suasana hati yang jauh lebih positif daripada orang yang tidak berolahraga dan secara positif mempengaruhi secara langsung partisipasi mereka dalam program ini (Matsouka, Bebetsos, Trigonis, \& Simakis, 2010). Akan tetapi, faktor lingkungan dan pribadi terkadang menghalangi lansia yang bercita-cita untuk menjaga kesehatan melalui rutinitas aktivitas jasmani (Mobily, 1982), sehingga para lansia membutuhkan motivasi secara eksternal, seperti dari anggota keluarganya.

Dengan aktivitas fisik tertentu, lansia memiliki kemampuan untuk mendapatkan efek positif dalam kekuatan, keseimbangan, dan kualitas hidup (Simmonds \& Wideman, 2010). Para lansia juga perlu mendapatkan edukasi tentang pentingnya aktivitas fisik dan latihan olahraga (Lohne-Seiler \& Torstveit, 2012).

Aktivitas jasmani yang rutin dilakukan walaupun ringan bentuknya akan tetap berpengaruh terhadap kesehatan lansia tersebut Aktivitas jasmani yang dilakukan secara teratur sangat penting bagi kesehatan lansia, bahkan pada lansia yang memiliki keterbatasan fungsional, bukti ilmiah menunjukkan bahwa aktivitas jasmani yang dilakukan secara rutin akan membantu meningkatkan kemampuan fungsional (cdc \& U.S. Department of Health and Human Services, 2008).

Jika lansia tidak melakukan aktivitas jasmani maka akan rentan terhadap penyakit akibat kurang gerak salah satunya obesitas. Kelebihan berat badan, obesitas, dan indeks massa tubuh (Body Mass Index) statis biasanya menyembunyikan sarkopenia yaitu kenaikan lemak tubuh tetapi kehilangan massa otot dan kapasitas fungsional pada lansia (Han, Tajar, \& Lean, 2011). Body Mass Index/BMI dapat dijadikan skala acuan pengukuran kondisi status gizi seseorang termasuk lansia (Markowitz, 2018).

Banyak manfaat dari partisipasi lansia melakukan aktivitas jasmani atau olahraga seperti memperbaiki fungsi kardiovaskuler, menurunkan hipertensi, dan meningkatkan kemampuan kapasitas kerja. Seperti hasil penelitian yang dilakukan oleh (Tittlbach et al., 2017), menunjukkan bahwa jenis kelamin, usia, dan status sosial ekonomi berperan penting terkait aktivitas fisik, kebugaran, dan kesehatan. Selain itu, parameter sosiodemografi seperti usia, jenis kelamin, status sosial ekonomi (SES) dan Indeks Massa Tubuh (BMI) dipertimbangkan karena mereka diketahui mempengaruhi kondisi kesehatan, kebugaran, dan aktivitas (Bouchard \& Shephard, 1994). Kedua hasil penelitian tersebut dijadikan sebagai dasar dari penelitian yang akan dilakukan. Peneliti merasa perlu mengetahui aspek lain yang dapat mempengaruhi atau memiliki hubungan dengan kebugaran jasmani lanjut usia seperti jenis kelamin, usia, dan body mass index (BMI). Hanya saja seberapa besar dampak atau 
hubungan tersebut perlu ditelusuri kebenarannya.

\section{METODE}

\section{Metode dan Desain}

Metode penelitian berkaitan dengan prosedur, alat, serta desain penelitian yang digunakan untuk mendapatkan tujuan yang diinginkan sehingga dihasilkan penelitian yang benar-benar ilmiah atas permasalahan-permasalahan penelitian. Jenis penelitian yang digunakan dalam penelitian ini adalah penelitian kuantitatif dengan menggunakan metode penelitian korelasional (Cresswel, 2013; Sugiyono, 2016)

Desain penelitian yang digunakan dalam penelitian ini adalah desain korelasional. Dalam penelitian ini terdiri dari tiga variabel bebas (X), yaitu jenis kelamin (X1), usia (X2), body mass index/BMI (X3), dan satu variabel terikat (Y) yaitu kebugaran jasmani.

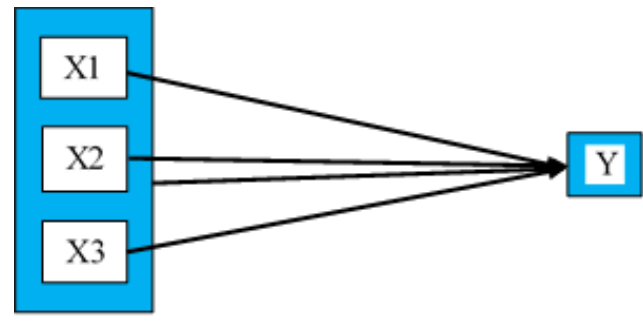

Gambar 1

Desain Penelitian Korelasional (diadaptasi dari Sugiyono, (2016)

Penelitian korelasi bertujuan untuk mengetahui hubungan antara dua variabel atau lebih (Sugiyono, 2016). Penggunaan metode ini diharapkan dapat mengungkap hubungan antara jenis kelamin, usia, dan body mass index (BMI) dengan kebugaran jasmani lansia. Peneliti ingin mengetahui aspek-aspek lain selain aspek fisik yang ada hubungannya dengan aspek kebugaran jasmani lansia.

\section{Partisipan}

Karena tujuan dan karakteristik tertentu, maka partisipan dalam penelitian ini yaitu orangorang lanjut usia yang tergabung dalam Klub Kebugaran Muhajirin, Pasirlayung Utara 246. Pemilihan klub kebugaran ini dianggap akan sangat membantu peneliti dan mempermudah proses penelitian, seperti proses koordinasi, perizinan, dan penentuan sampel. Alasan peneliti memilih dan menentukan orang-orang lansia yang tergabung dalam klub ini yaitu:

- Salah satu klub kebugaran khusus lansia yang ada di Kota Bandung.

- Klub ini masih aktif dalam berbagai penyelenggaraan kegiatan keolahragaan bagi lansia.

- Memiliki program latihan yang telah berjalan.

Beberapa alasan tersebut di atas menjadi dasar pertimbangan dari penentuan partisipan (populasi dan sampel) dalam penelitian ini. Populasi dalam penelitian ini adalah orangorang lansia yang tergabung dalam Klub Kebugaran Muhajirin, Pasirlayung utara 246 yang berjumlah 54 orang.

Sedangkan sampel terdiri dari sejumlah anggota yang dipilih dari populasi yang berusia 60 tahun ke atas menggunakan teknik Non Probability Sampling (Sugiyono, 2016). Jenis Non Probability Sampling yang digunakan dalam penentuan sampel penelitian adalah purposive sampling. Alasannya bahwa tidak semua sampel memiliki kriteria sesuai dengan yang telah ditentukan.

Secara umum, semakin besar sampel semakin baik, akan tetapi ada jumlah batas minimal yang harus diambil oleh peneliti yaitu sebanyak 30 sampel atau lebih (Cohen, Manion, \& Morrison, 2017; Sugiyono, 2016). Dari penjelasan tentang ukuran sampel dan kriteria sampel di atas, maka jumlah sampel adalah 37 orang lansia yang memenuhi kriteria penelitian dengan usia 60 tahun ke atas.

\section{Instrumen}

Penelitian ini menggunakan instrumen battery test untuk mengukur kebugaran jasmani lansia yaitu Senior Fitness Test dengan validitas yang kuat dan rentang nilai reliabilitas ( $\mathrm{R}$ Value) sebesar $80 \mathrm{~s} / \mathrm{d}$ 96, hal ini menunjukkan keandalan yang dapat diterima untuk semua item tes (Rikli \& Jones, 2013). Unsur-unsur kebugaran jasmani yang diukur melalui tes ini yaitu muscular strength (lower and upper body), aerobic endurance, flexibility (lower and upper body), agility and dynamic balance, and body mass index (BMI). 


\section{Prosedur}

Sebelum melakukan tes, partisipan melakukan pemanasan termasuk stretching (peregangan) antara 5 sampai 8 menit.

Rangkaian Senior Fitness Test yang sudah diadopsi dan diadaptasi akan dijabarkan sebagai berikut:

\section{30 Second Chair Stand Test}

Tujuan dari tes ini yaitu untuk mengukur kekuatan tubuh bagian bawah. Peralatan yang dibutuhkan adalah stopwatch, kursi lipat dengan tinggi tempat duduknya $43 \mathrm{~cm}$. Senderkan kursi ke dinding agar tidak tergelincir.

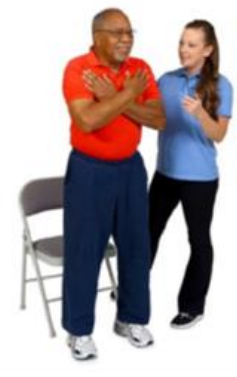

Gambar 2

30 Second Chair Stand Test

Prosedur pelaksanaan tes; instruksikan sampel untuk duduk ditengah kursi dengan posisi badan tegak, silangkan tangan di depan dada. Ketika ada aba-aba "mulai" sampel berdiri tegak dan duduk kembali seperti posisi awal. Sebelum tes dimulai, sampel berkesempatan untuk mencoba satu atau dua kali. Berikan contoh secara perlahan sehingga sampel melakukan tes dengan benar. Nilai diberikan pada setiap gerakan yang dilakukan dengan sempurna selama 30 detik.

\section{30 Second Arm Curl Test}

Tes ini mengukur kekuatan tubuh bagian atas. Peralatan yang dibutuhkan adalah stopwatch, kursi lipat, dumbbell seberat $2.3 \mathrm{~kg}$ untuk perempuan dan 3,6 kg untuk laki-laki.

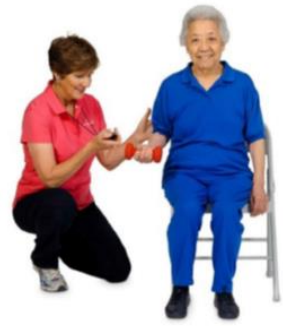

Gambar 3

30 Second Arm Curl Test
Prosedur pelaksanaannya yaitu sampel duduk tegak dengan sisi tubuh yang dominan berada di pinggir kursi. Tangan kanan memegang dumbbell dengan kuat, sedangkan tangan kiri memegang kursi untuk menjaga keseimbangan. Selama melakukan tes, posisi badan harus tetap tegak dan lengan tidak boleh mengayun. Berikan contoh dengan gerakan perlahan, posisi awal lengan harus lurus ke bawah kemudian tekuk maksimal ke atas. Sampel diberikan kesempatan untuk mencoba 1 atau 2 kali. Ketika ada aba-aba "mulai" sampel melakukan gerakan tes secara maksimal selama 30 detik. Nilai diberikan pada setiap gerakan yang dilakukan dengan sempurna selama 30 detik.

\section{Height and Weight}

Tujuan dari tes ini adalah untuk mengukur indeks masa tubuh. Peralatan yang dibutuhkan adalah timbangan, meteran, selotip, penggaris.

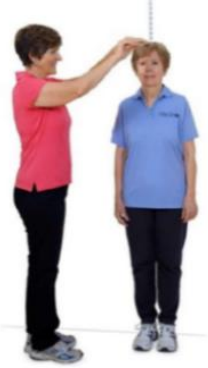

Gambar 4

Mengukur Height and Weight

Prosedur yang dilakukan yaitu lepaskan sepatu ketika mengukur berat dan tinggi badan. Masukan hasil pengukuran tinggi dan berat badan pada rumus BMI $=\mathrm{kg} / \mathrm{m} 2$.

\section{2 Minute Step Test}

Tes ini merupakan alternatif untuk mengukur daya tahan aerobik. Peralatan yang dibutuhkan adalah stopwatch, meteran, selotip, alat bantu untuk menghitung jumah gerakan. Untuk nilai yang maksimal, 1 hari sebelum tes sampel melakukan latihan selama 2 menit. Angkat lutut tinggi sesuai dengan yang telah ditentukan (berikan tanda menggunakan selotip pada kursi atau dinding). 


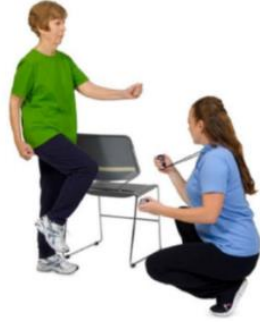

Gambar 5

2 Minute Step Test

Prosedur pelaksanaan tes yaitu, ketika ada aba-aba "mulai" sampel melakukan gerakan mengangkat lutut dengan maksimal selama 2 menit. Gerakan dihitung apabila lutut diangkat sesuai target yang ditentukan. Jika sampel sudah terlihat kelelahan, intruksikan untuk istirahat dengan resiko waktu tetap berjalan.

5. Chair Sit-and-Reach Test

Tujuan dari tes ini adalah untuk mengukur fleksibilitas tubuh bagian bawah (terutama hamstring). Peralatan yang digunakan adalah kursi lipat dengan tinggi $43 \mathrm{~cm}$, penggaris, dan senderkan kursi kedinding agar tidak tergelincir.

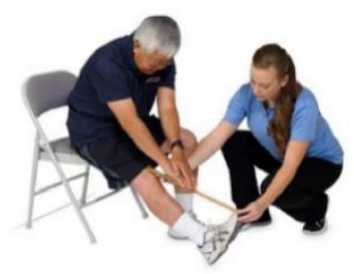

Gambar 6

Chair Sit-and-Reach Test

Prosedurnya yaitu sampel duduk diujung kursi. Kemudian berusaha untuk menjangkau atau menyentuh ujung kaki yang diluruskan (lebih jauh lebih baik), sedangkan kaki lainnya ditekuk. Sampel diberikan 2 kali kesempatan tes, diambil nilai terbaik dari 2 kali kesempatan tersebut. Menggunakan kaki yang mana saja. Ukur jarak jangkauan dengan titik 0 berada dijari tengah kaki. Jika jangkauan lebih pendek dari titik 0 , maka jarak atau nilainya adalah (-) ; jika jari tengah tersentuh maka nilainya 0 ; dan jika jangkauan lebih dari jari tengah maka nilai jaraknya (+).

\section{Back Scratch Test}

Tujuan dari tes ini adalah untuk mengukur fleksibilitas tubuh bagian atas (bahu). Peralatan yang dibutuhkan adalah penggaris.

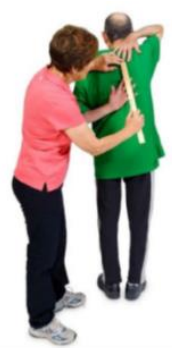

Gambar 7

Back Scratch Test

Prosedurnya yaitu sampel berdiri tegak kemudian putar kebelakang atas salah satu tangan, sedangkan tangan lainnya putar kebelakang bawah. Usahakan jari-jari dari kedua tangan bertemu di punggung. Sampel diberikan 2 kali kesempatan untuk mencoba sebelum tes. Jangan dibantu ketika sampel melakukan latihan tes ini. Penilaian dilakukan dengan memberikan 2 kali kesempatan tes, diambil nilai yang terbaik antara 2 tes tersebut. Nilai (-) jika jari tengah tidak saling bersentuhan, nilai 0 jika ujung jari tengah hanya bersentuhan, dan nilai (+) jika jari tengah saling melewati. Hitung dari ujung jari tengah keujung jari tengah lainnya untuk memberikan nilai.

7. 8-Foot Up-and-Go Test

Tujuan dari tes ini adalah untuk mengukur kelincahan dan keseimbangan dinamis. Perlengkapan yang dibutuhkan adalah stopwatch, kursi lipat dengan tinggi $43 \mathrm{~cm}$, meteran dan cone atau tanda lainnya. Senderkan kursi kedinding, letakkan cone sejauh 2,4 m dari kursi.

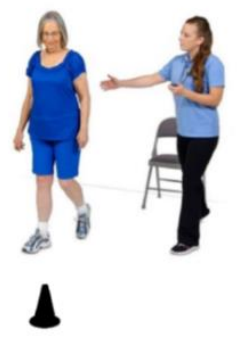

$$
\begin{gathered}
\text { Gambar } 8 \\
\text { 8-Foot Up-and - Go Test }
\end{gathered}
$$

Prosedurnya yaitu sampel duduk tegak diatas kursi, kedua tangan diatas paha. Ketika ada aba-aba (mulai), sampel berdiri kemudian berjalan cepat mengelilingi cone dan kembali duduk dikursi. Waktu dimulai ketika tester memberi tanda mulai dan waktu berhenti ketika 
sampel telah kembali duduk dkursi. Sampel diberikan 2 kali kesempatan tes, diambil waktu terbaik antara ke 2 tes tersebut.

\section{6 Minute Walk Test*}

Tujuan dari tes ini adalah untuk mengukur daya tahan aerobik. Peralatan yang dibutuhkan adalah meteran, 2 stopwatch, 4 cone, selotip, spidol, 12-15 batang stik es krim/sedotan per sampel untuk mengetahui jumlah lap yang sudah dilalui, kursi dan papan nama. Prosedur pelaksanaannya yaitu 2 atau lebih sampel di tes dalam waktu yang bersamaan agar saling memotivasi, bahkan dapat dilakukan oleh 6-12 sampel dalam sekali waktu. Nilai yang dicatat adalah jarak yang ditempuh oleh sampel selama 6 menit berjalan kaki.

Sebagai catatan, jika 6 Minute Walk Test digunakan sebagai pengganti dari 2 - Minute Step Test, maka urutan pelaksanaanya setelah seluruh tes lainnya selesai dilakukan (paling akhir).

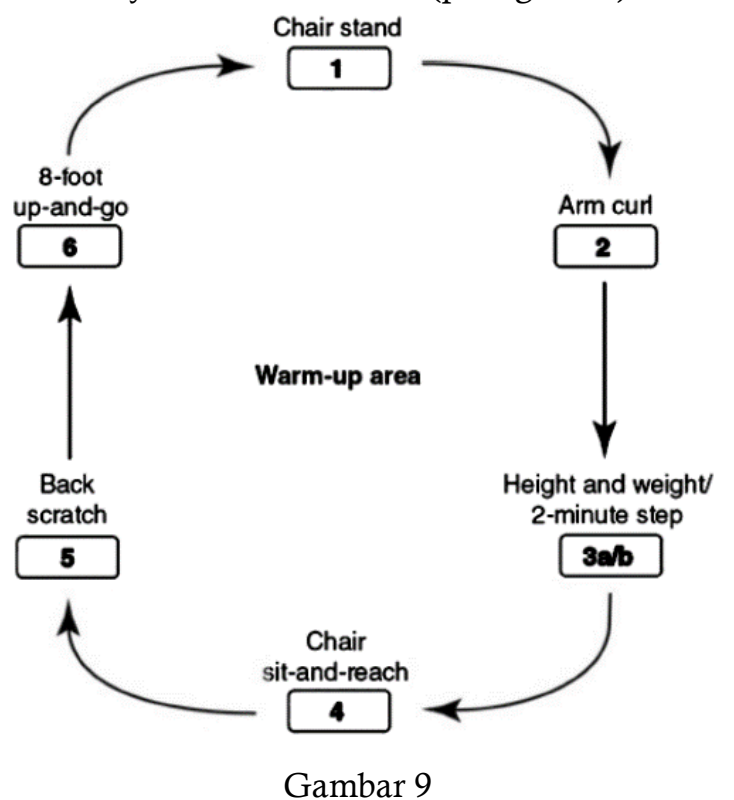

Alur Pelaksanaan Senior Fitness Test Apabila tidak memungkinkan untuk melakukan 6 Minute Walk Test (karena area terbatas atau cuaca yang buruk), kemudian menjadikan 2 Minute Step Test pada alur rangkaian tes setelah mengukur tinggi dan berat badan. Jika kedua tes daya tahan aerobik tersebut akan dilakukan, disarankan agar 2 - Minute Step Test disertakan dalam alur rangkaian tes. Sedangkan 6 Minute Walk Test dilakukan pada hari yang berbeda. Hal ini atas pertimbangan kemampuan jasmani yang dimiliki oleh lansia, karena untuk beberapa lansia itu merupakan sesuatu hal yang dianggap cukup berat untuk dilakukan.

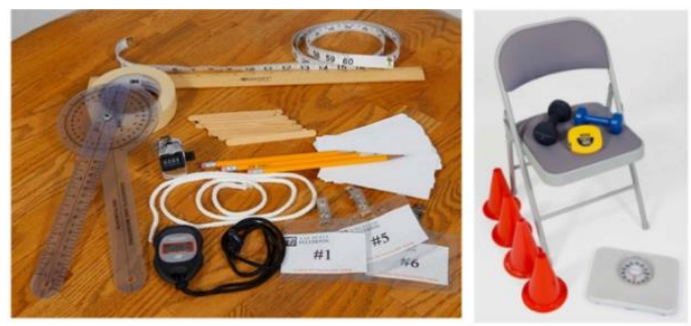

Gambar 10

\section{Peralatan Tes}

Peralatan yang dibutuhkan dalam pelaksanaan tes diantaranya stopwatch, penggaris, meteran, stik es krim, alat tulis (pulpen/pensil), kertas catatan (formulir tes), lakban, kursi, dumbbells, corong/cones, timbangan dan alat ukur tinggi badan.

\section{Analisis Data}

Analisis data dilakukan dengan tujuan untuk menguji hipotesis dalam rangka penarikan simpulan. Teknik analisis data dalam penelitian ini terdiri dari beberapa langkah, yaitu pertama menghitung rata-rata dan simpangan baku menggunakan aplikasi Statistical Package for the Social Sciences (SPSS) versi 18. Selanjutnya menghitung normalitas data menggunakan uji normalitas Kolmogorov-Smirnov pada aplikasi SPSS versi 18. Format pengujiannya dengan membandingkan nilai probabilitas (p) atau signifikansi (Sig.) dengan derajat kebebasan (dk) $\alpha=0,05$. Uji kebermaknaannya yaitu jika nilai Sig. atau P-value $>0,05$ maka data dinyatakan normal. Sedangkan jika nilai Sig. atau P-value < 0,05 maka data dinyatakan tidak normal. Sedangkan untuk uji signifikansi apabila nilainya (Sig.) $<0,05$ berarti signifikan dan hipotesis diterima.

\section{HASIL}

Pengolahan data dalam penelitian ini dilakukan dengan cara membuat skala ordinal dari setiap variabel penelitian menggunakan software Statistical Package for the Social Sciences (SPSS) versi 18 (Inandia, 2012). 
Table 1. Deskripsi Data

\begin{tabular}{lccr}
\hline Variabel & N & Mean & Std. Dev \\
\hline Jenis Kelamin & 37 & 1.4865 & .50671 \\
Usia & 37 & 1.8649 & .34658 \\
BMI & 37 & 1.5405 & .73009 \\
Kebugaran Jasmani & 37 & 2.7297 & .50819 \\
Valid N (listwise) & 37 & & \\
\hline
\end{tabular}

Berdasarkan Tabel 1, bahwa nilai ratarata variabel jenis kelamin yaitu 1,49 dengan simpangan baku 0,51 . Nilai rata-rata variabel usia yaitu 1,86 dengan simpangan baku 0,35 . Nilai rata-rata variabel body mass index (BMI) yaitu 1,54 dengan simpangan baku 0,73 . Sedangkan nilai rata-rata variabel kebugaran jasmani yaitu 2,73 dengan simpangan baku 0,51.

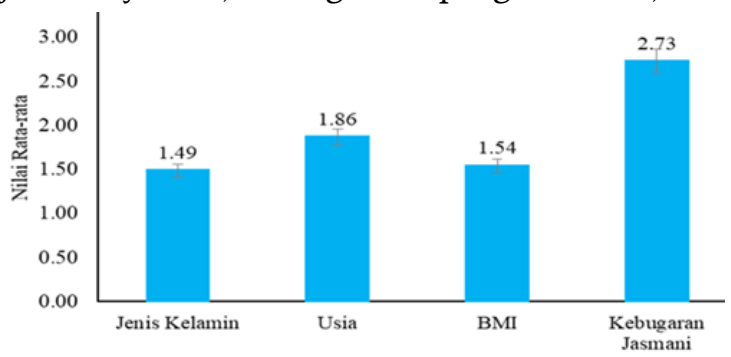

Grafik 1

Nilai Rata-rata Setiap Variabel Penelitian

Dari daftar nilai rata-rata keempat variabel penelitian tersebut di atas, variabel kebugaran jasmani memiliki nilai paling besar sedangkan terkecil adalah variabel jenis kelamin. Sedangkan nilai standar deviasi yang paling besar adalah pada variabel body mass index (BMI), terkecil adalah variabel usia.

\section{Jenis Kelamin}

Sebanyak 18 orang atau 49\% jumlah sampel berjenis kelamin perempuan, sedangkan sisanya

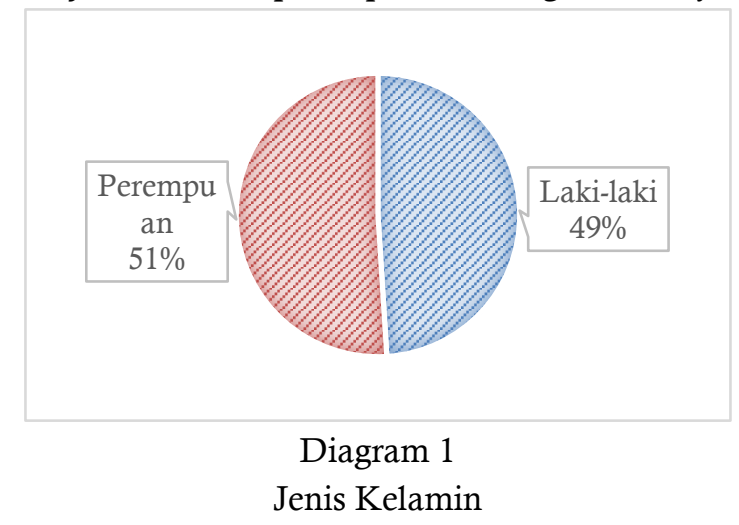

sebanyak 19 orang atau 51\% jumlah sampel berjenis kelamin laki-laki. Sehingga jumlah keseluruhan sampel sebanyak 37 orang lansia.

\section{Usia}

Jika dikelompokkan menurut jenis kelamin, rata-rata usia laki-laki lebih tinggi dibandingkan dengan rata-rata usia perempuan.

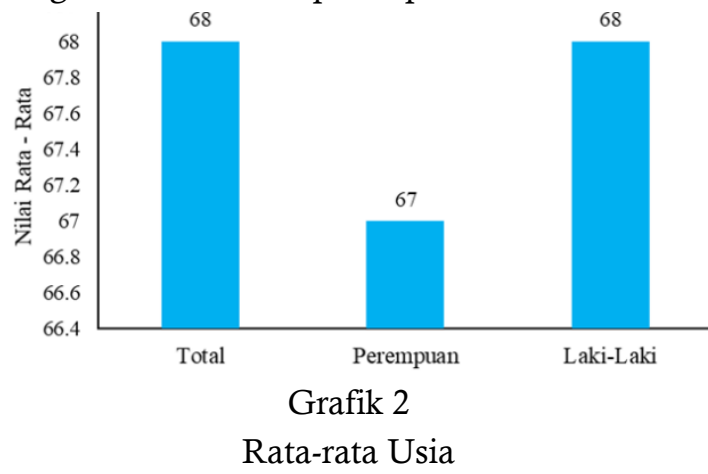

Grafik 2 di atas menunjukkan nilai ratarata usia sampel penelitian yaitu 68 tahun.

\section{Body Mass Index (BMI)}

Nilai rata-rata BMI perempuan yaitu 25,90 lebih besar 0,09 dibandingkan laki-laki yaitu 25,81. Akan tetapi, secara keseluruhan nilai rata-rata BMI sebesar 25,85 yang berarti bahwa kondisi BMI-nya termasuk dalam kategori berat badan berlebih/Overweight (Nihiser et al., 2007; World Health Organization, 2004, 2006).

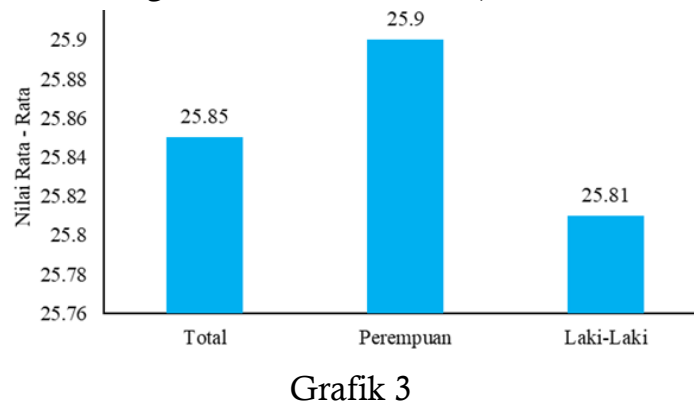

Nilai Rata-rata Body Mass Index (BMI)

\section{Kebugaran Jasmani}

Komponen kebugaran jasmani lanjut usia yang diukur dalam penelitian ini yaitu mengacu pada instrumen battery test untuk mengukur kebugaran jasmani orang lansia yaitu Senior Fitness Test (Rikli \& Jones, 2013) yang terdiri dari muscular strength (lower and upper body), aerobic endurance, flexibility (lower and upper body), agility and dynamic balance, and body mass index (BMI). 


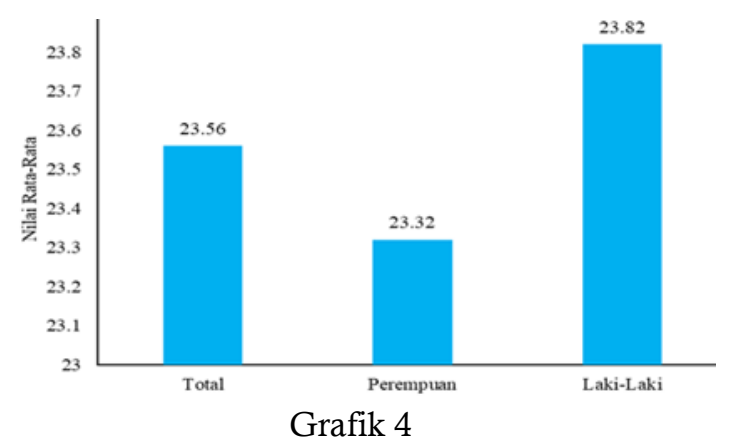

Nilai Rata-rata Kebugaran Jasmani

Grafik 4 menunjukkan bahwa laki-laki memiliki nilai rata-rata kebugaran jasmani lebih

\section{Uji Hipotesis}

Tabel 3 di bawah ini menunjukkan nilai hubungan (R) sebesar 0,526, artinya bahwa jenis kelamin, usia, dan body mass index (BMI) secara simultan dengan kebugaran jasmani memiliki tingkat hubungan sedang. Nilai koefisien determinasi (R Square) sebesar 0,277 atau setara $27,7 \%$ yang berarti bahwa jenis kelamin, usia, dan body mass index (BMI) secara simultan Tabel 3. Uji Hipotesis

\begin{tabular}{|c|c|c|c|c|}
\hline Model & $\mathrm{R}$ & R Square & Adjusted R Square & Std. Error of the Estimate \\
\hline 1 & $.526^{\mathrm{a}}$ & .277 & .211 & .45130 \\
\hline
\end{tabular}

a. Predictors: (Constant), Jenis Kelamin, Usia, BMI

Tabel 4. Uji Signifikansi

\begin{tabular}{llrrrrr}
\hline Model & Sum of Squares & \multicolumn{1}{c}{ df } & Mean Square & F & Sig. \\
\hline 1 & Regression & 2.576 & 3 & .859 & 4.216 & $.012^{\mathrm{a}}$ \\
Residual & 6.721 & 33 & .204 & & \\
$\quad$ Total & 9.297 & 36 & & & \\
\hline
\end{tabular}

a. Predictors: (Constant), Jenis Kelamin, Usia, BMI

b. Dependent Variable: Kebugaran Jasmani

Dari hasil uji hipotesis tersebut terlihat bahwa terdapat hubungan yang signifikan antara jenis kelamin, usia, dan body mass index (BMI) dengan kebugaran jasmani lansia.

\section{PEMBAHASAN}

Dari hasil penelitian menunjukkan bahwa terdapat hubungan antara jenis kelamin, usia, dan body mass index (BMI) dengan kebugaran jasmani lansia dengan tingkat hubungannya pada kategori sedang. Data di lapangan menunjukkan bahwa lanjut usia laki-laki memiliki tingkat kebugaran jasmani lebih baik daripada perempuan, artinya bahwa jenis tinggi 0,50 yaitu 23,82 dibandingkan dengan perempuan yaitu 23,32.

Analisis persentase hasil tes komponen kebugaran jasmani lansia terdiri dari tiga kategori.

Tabel 2. Kategori Penilaian

\begin{tabular}{ll}
\hline Kategori & Skor \\
\hline Di Atas Rata-rata & $76-100$ \\
\hline Normal & $26-75$ \\
\hline Di Bawah Rata-rata & $0-25$ \\
\hline
\end{tabular}

Sumber: Diadaptasi dari (Rikli \& Jones, 2013)

berpengaruh terhadap kebugaran jasmani sebesar 27,7\%. Kemudian, Tabel 4 menunjukkan nilai Sig. sebesar 0,012, lebih kecil dari nilai signifikansi $\alpha=0,05$ atau 0,012 < 0,05, artinya bahwa jenis kelamin, usia, dan body mass index (BMI) secara simultan berkorelasi dengan kebugaran jasmani lanjut usia. kelamin berhubungan dengan kebugaran jasmani. Selanjutnya, fakta di lapangan menunjukkan bahwa faktor usia tidak berhubungan dengan kebugaran jasmani lanjut usia. Hal tersebut dilihat dari nilai kebugaran jasmani yang lebih baik dari lanjut usia yang berumur lebih tua dibandingkan dengan lanjut usia yang lebih muda, baik pada laki-laki maupun perempuan. Fakta berikutnya menunjukkan bahwa BMI tidak berhubungan dengan kebugaran jasmani lanjut usia. Akan tetapi, BMI dapat dipengaruhi oleh kebugaran jasmani melalui proporsi berat dan tinggi badan hasil dari melakukan aktivitas jasmani. 
Tentang hubungan jenis kelamin dengan kebugaran jasmani lansia. Tittlbach et al., (2017) pada hasil penelitiannya menunjukkan perbedaan tingkat kebugaran jasmani antara laki-laki dengan perempuan pada setiap rentang usia sampel (skor kebugaran jasmani laki-laki lebih tinggi daripada perempuan). Berkaitan dengan penelitian ini, lansia berjenis kelamin laki-laki memiliki tingkat kebugaran jasmani yang lebih baik dibandingkan dengan perempuan. Hal tersebut dapat diakibatkan oleh berbagai hal, seperti perbedaan aktivitas jasmani yang dilakukan (Inandia, 2012), perbedaan gaya hidup (De Groot, Verheijden, De Henauw, Schroll, \& Van Staveren, 2004), perbedaan hormon, perbedaan organ biologis, dan perbedaan kekuatan otot antara laki-laki dengan perempuan (Aoyagi \& Shephard, 2013).

Dalam penelitian ini, terdapat beberapa fakta yang menunjukkan bahwa subjek yang berusia lebih tua (De Groot et al., 2004) pada laki-laki dan perempuan memiliki nilai kebugaran jasmani yang lebih baik daripada yang lebih muda. Jadi, dapat disimpulkan bahwa tidak ada hubungan antara usia dengan kebugaran jasmani lanjut usia. Berbanding terbalik dengan Tittlbach et al., (2017) yang dalam penelitiannya mengindikasikan bahwa menurunnya parameter kesehatan (seperti, menurunnya kebugaran jasmani, meningkatnya keluhan fisik, dan meningkatnya skor BMI) akibat dari bertambahnya usia (rentang usia 3377 tahun). Pengaruh usia terhadap kebugaran jasmani akan terlihat ketika seseorang berada pada usia 11-18 tahun atau masa remaja (Gakhar \& Malik, 2017). Dari pembahasan di atas, artinya bahwa hasil penelitian ini membuat temuan baru karena menunjukkan kenyataan yang berbeda dengan hasil penelitian terdahulu. Hal tersebut dapat dipengaruhi oleh faktorfaktor lain yang secara langsung berhubungan dengan kebugaran jasmani seperti, active lifestyle, pola hidup sehat, dan jenis aktivitas jasmani yang dilakukan (Ogilvie et al., 2011; Rousseau, 1989; Van Den Brink et al., 2005)

Hasil penelitian menunjukkan bahwa penurunan tingkat kebugaran jasmani secara signifikan akan meningkatkan keluhan fisik dan
BMI (Dishman et al., 2015; Holth, Werpen, Zwart, \& Hagen, 2008; Tittlbach et al., 2017). Untuk mengatasi masalah tersebut maka dengan melakukan gaya hidup sehat dan aktivitas fisik secara teratur dan terukur akan berhubungan dengan kebugaran jasmani dan kelebihan berat badan pada lanjut usia (Rauner et al., 2013).

Dari pembahasan di atas, dapat dimakni bahwa lansia harus melakukan pola hidup sehat dengan selalu menjaga kebugaran jasmani melalui aktivitas fisik atau olahraga secara teratur dan terukur, pola makan sehat, dan istirahat yang cukup untuk mendapatkan indeks massa tubuh/BMI yang ideal. Banyak manfaat jika memiliki BMI ideal seperti terhindar dari penyakit non-infeksi yang diakibatkan oleh obesitas (Han et al., 2011).

Berdasarkan hasil penelitian bahwa jenis kelamin, usia, dan body mass index (BMI) secara bersama-sama berkorelasi dengan kebugaran jasmani lansia. Hal ini berarti bahwa hasil penelitian yang telah dilakukan mendukung dan melengkapi hasil penelitian terdahulu. Penelitian Tittlbach et al., (2017), hasilnya menunjukkan bahwa jenis kelamin, usia, dan status sosial ekonomi berperan penting terkait aktivitas fisik, kebugaran, dan kesehatan. Selanjutnya penelitian Bouchard \& Shephard, (1994), hasilnya menunjukkan bahwa parameter sosiodemografi seperti usia, jenis kelamin, status sosial ekonomi (SES) dan Indeks Massa Tubuh (BMI) mempengaruhi kondisi kesehatan, kebugaran, dan aktivitas. Kebugaran jasmani lanjut usia secara langsung dipengaruhi oleh aktivitas jasmani yang dilakukannya (Rousseau, 1989), dan secara tidak langsung dipengaruhi oleh ketiga faktor lain, yaitu jenis kelamin, usia, dan body mass index (BMI).

\section{KESIMPULAN}

Dari hasil penelitian ini, dapat ditarik kesimpulan bahwa jenis kelamin, usia, dan BMI memiliki hubungan dengan kebugaran jasmani lanjut usia walaupun tingkat hubungannya sedang berdasarkan pedoman interpretasi koefisien korelasi. Jadi, selain ketiga faktor tersebut yang secara tidak langsung 
berhubungan dengan kebugaran jasmani, lanjut usia harus tetap melakukan pola hidup aktif dan sehat untuk menjaga kebugaran jasmani salah satunya melalui aktivitas fisik atau olahraga.

\section{REFERENSI}

Aoyagi, Y., \& Shephard, R. J. (2013). Sex differences in relationships between habitual physical activity and health in the elderly: Practical implications for epidemiologists based on pedometer/accelerometer data from the Nakanojo Study. Archives of Gerontology and Geriatrics.

https://doi.org/10.1016/j.archger.2012.11 .006

Azizah, L. M. (2011). Keperawatan Lanjut Usia. Yogyakarta: Graha Ilmu, 2011. https://doi.org/10.1017/CBO9781107415 324.004

Bouchard, C., \& Shephard, R. (1994). Physical activity, fitness, and health: The model and key concepts. DisabilityPhysical Activity, Fitness, and Health: International Proceedings and Consensus Statement and Rehabilitation.

cdc, \& U.S. Department of Health and Human Services. Physical Activity Guidelines for Americans (2008), Health (San Francisco) $\S$ (2008) https://doi.org/10.1161/CIRCOUTCOM ES.118.005263

Chen, T., Hui, E. C. M., Lang, W., \& Tao, L. (2016). People, recreational facility and physical activity: New-type urbanization planning for the healthy communities in China. Habitat International, 58, 12-22. https://doi.org/10.1016/j.habitatint.2016. 09.001

Cohen, L., Manion, L., \& Morrison, K. (2017). Research Methods in Education. Research Methods in Education. https://doi.org/10.4324/9781315456539

Cresswel, J. (2013). Qualitative, quantitative, and mixed methods approaches. Research design. https://doi.org/10.2307/3152153

Dai Jun. (2015). Impact of Gender, Age Groups and Physical Activity on the Functional
Fitness of the Elderly. Journal of Capital Institute of Physical Education.

De Groot, L. C. P. M. G., Verheijden, M. W., De Henauw, S., Schroll, M., \& Van Staveren, W. A. (2004). Lifestyle, nutritional status, health, and mortality in elderly people across Europe: A review of the longitudinal results of the SENECA study. Journals of Gerontology - Series A Biological Sciences and Medical Sciences. https://doi.org/10.1093/gerona/59.12.12 77

Dishman, R. K., Sui, X., Church, T. S., Kline, C. E., Youngstedt, S. D., \& Blair, S. N. (2015). Decline in cardiorespiratory fitness and odds of incident sleep complaints. Medicine and Science in Sports and Exercise. https://doi.org/10.1249/MSS.000000000 0000506

Emerson, P. (1991). Exercise and the elderly: A group counseling approach. Journal for Specialists in Group Work, 16(3), 152-158. https://doi.org/10.1080/01933929108415 602

Gakhar, I., \& Malik, S. L. (2017). Physical Fitness: Age Change and sex Differences Among the Jats of Delhi. The Anthropologist, 1(1), 37-50. https://doi.org/10.1080/09720073.1999.1 1890572

Giriwijoyo, S., Komariyah, L., \& Kartinah, N. T. (2007). Ilmu Kesehatan olahraga (Sports Medicine). Pendidikan Olahraga.

Gram, M., Dahl, R., \& Dela, F. (2014). Physical inactivity and muscle oxidative capacity in humans. European Journal of Sport Science, 14(4), 376-383 https://doi.org/10.1080/17461391.2013.8 23466

Han, T. S., Tajar, A., \& Lean, M. E. J. (2011). Obesity and weight management in the elderly. British Medical Bulletin. https://doi.org/10.1093/bmb/1dr002

Holth, H. S., Werpen, H. K. B., Zwart, J. A., \& Hagen, K. (2008). Physical inactivity is associated with chronic musculoskeletal complaints 11 years later: Results from the Nord-Trøndelag Health Study. BMC 
Musculoskeletal

Disorders.

https://doi.org/10.1186/1471-2474-9-159

Inandia, K. (2012). Kejadian Obesitas Berdasarkan Persen Lemak Tubuh dan Rasio Lingkar Pinggang, Pinggul Serta Fakto-faktor Lain Yang Berhubungan Pada Prelansia dan Lansia Kelurahan Depok Jaya. Universitas Indonesia.

Justine, M., Azizan, A., Hassan, V., Salleh, Z., \& Manaf, H. (2013). Barriers to participation in physical activity and exercise among middle-aged and elderly individuals. Singapore Medical Journal. https://doi.org/10.11622/smedj.2013203

Kyröläinen, H., Santtila, M., Nindl, B. C., \& Vasankari, T. (2010). Physical fitness profiles of young men: associations between physical fitness, obesity and health. Sports Medicine (Auckland, N.Z.), 40(11), 907-920. https://doi.org/10.2165/11536570000000000-00000

Lohne-Seiler, H., \& Torstveit, M. K. (2012). The importance of physical activity and training for older adults . Viktigheten Av Fysisk Aktivitet Og Trening Blant Elder.

Markowitz, J. S. (2018). Body mass index (BMI). In SpringerBriefs in Public Health. https://doi.org/10.1007/978-3-319-772035_5

Matsouka, O., Bebetsos, E., Trigonis, I., \& Simakis, S. (2010). The effects of an outdoor exercise program on mood states among the elderly. World Leisure Journal, 52(1), $\quad 34-40$. https://doi.org/10.1080/04419057.2010.9 674620

Mobily, K. E. (1982). Motivational aspects of exercise for the elderly: Barriers and solutions. Physical and Occupational Therapy in Geriatrics, 1(4), 43-54. https://doi.org/10.1080/J148V01N04_06

Nihiser, A. J., Lee, S. M., Wechsler, H., McKenna, M., Odom, E., Reinold, C., ... Grummer-Strawn, L. (2007). Body mass index measurement in schools. Journal of School Health. https://doi.org/10.1111/j.1746- 1561.2007.00249.x

Ogilvie, D., Lamb, K. E., Ferguson, N. S., \& Ellaway, A. (2011). Recreational physical activity facilities within walking and cycling distance: Sociospatial patterning of access in Scotland. Health and Place, 17(5), 1015-1022.

https://doi.org/10.1016/j.healthplace.201 1.07 .003

Oktriani, S., Solihin, I., \& Komariyah, L. (2019). Physical Activity in Elderly: An Analysis of Type of Sport Taken by Elderly in Bandung. JURNAL PENDIDIKAN JASMANI DAN OLAHRAGA, 4(1), 62-67. Retrieved from https://ejournal.upi.edu/index.php/penja s/article/view/15059

Papalia, D. E., Olds, S. W., \& Feldman, R. D. (2007). Human development, 10th ed. Human development, 10th ed.

Rauner, A., Mess, F., \& Woll, A. (2013). The relationship between physical activity, physical fitness and overweight in adolescents: A systematic review of studies published in or after 2000. BMC Pediatrics, 13(1). https://doi.org/10.1186/1471-243113-19

Rikli, R. E., \& Jones, c. J. (2013). Senior Fitness Test. United States: Human Kinetics.

Rousseau, P. (1989). Exercise in the elderly. Postgrad.Med, $\quad 85(6), \quad 113-116$. https://doi.org/10.1080/00325481.1989.1 1700692

Salguero, A., Martínez-García, R., Molinero, O., \& Márquez, S. (2011). Physical activity, quality of life and symptoms of depression in community-dwelling and institutionalized older adults. Archives of Gerontology and Geriatrics. https://doi.org/10.1016/j.archger.2010.10 .005

Setiawan, A., \& Oktriani, S. (2017). Physical Activity: Sports which are Done by Elders. In 2nd International Conference on Sport Science, Health and Physiscal Education (Vol. 1, pp. 292-294). Scitepress Digital Library. https://doi.org/10.5220/00070602029202 94 
Short, L., \& Leonardelli, C. A. (1987). The Effects of Exercise on the Elderly and Implications for Therapy, 5(3), 65-73.

Simmonds, M. J., \& Wideman, T. H. (2010). Physical Therapy and Rehabilitation. In Clinical Pain Management: A Practical Guide. https://doi.org/10.1002/9781444329711. $\operatorname{ch} 22$

Sugiyono. (2016). Metode Penelitian dan Pengembangan (Research and Development/R\&D). Bandung: Alfabeta. https://doi.org/10.1016/j.drudis.2010.11. 005

Tittlbach, S. A., Jekauc, D., Schmidt, S. C. E., Woll, A., Tittlbach, S. A., Jekauc, D., ... Woll, A. (2017). The relationship between physical activity, fitness, physical complaints and BMI in German adults results of a longitudinal study, 1391(July). https://doi.org/10.1080/17461391.2017.1 347963

Van Camp, S. P., \& Boyer, J. L. (1989). Exercise guidelines for the elderly (part 2 of 2). Physician \& Sportsmedicine, 17(5), 83-86;88. https://doi.org/10.1080/00913847.1989.1 1709784

Van Den Brink, C. L., Picavet, H., Van Den Bos, G. A., Giampaoli, S., Nissinen, A., \& Kromhout, D. (2005). Duration and intensity of physical activity and disability among European elderly men. Disability and Rehabilitation, 27(6), 341-347. https://doi.org/10.1080/09638280400018 452

World Health Organization. (n.d.). World Health Organization. Retrieved from https://www.who.int/

World Health Organization. (2004). BMI classification. Pharmacotherapy. https://doi.org/10.1001/archinte.1996.00 440040101011

World Health Organization. (2006). WHO :: Global Database on Body Mass Index. Generic. https://doi.org/10.1136/bjsm.2004.01250 0 